\title{
CARDIOVASCULAR ADJUSTMENTS DURING GRADED EXERCISE STRESS
}

\author{
Jonas Poderys, Alfonsas Buliuolis, Kristina Poderienė, Vilma Papievienė \\ Lithuanian Academy of Physical Education, Kaunas, Lithuania
}

\begin{abstract}
Research background and hypothesis. Cardiac function provides an adequate blood supply to all organs thus changes in the performance and functional state of cardiac muscles during exercising are very important.

Research aim. The aim of the study was to find out the peculiarities in adjustment of cardiovascular system in dependence on the type of adaptation to physical loads during graded stress.

Research methods. The study participants, 17 non-athletes, 23 endurance, 19 sprint and 21 combat sport athletes, underwent a bicycle ergometry of incremental increase in provocative workload (graded stress). A 12-lead ECG was reordered and a computerized program allowed to measure ECG parameter, the ratio of JT/RR intervals and the velocity of adaptation of cardiovascular system to exercising $\left(\mathrm{V}_{\mathrm{Ad}}\right)$, by calculating the difference between the relative changes of $\mathrm{JT}$ interval and $\mathrm{RR}$ interval as a difference: $\mathrm{V}_{\mathrm{Ad}}=\left(\mathrm{JT}_{\mathrm{i}} / \mathrm{JT}_{0}\right) 100 \%-\left(\mathrm{RR}_{\mathrm{i}} / \mathrm{RR}_{0}\right) 100 \%$.

Research results. No significant functional ischemia was found in endurance cohort during the graded stress while it was expressed in non-athletes' cohort and slightly smaller in sprint and combat cohorts. Maximal values of other ECG or ABP parameters registered during graded stress did not reveal significant differences between cohorts.

Discussion and conclusions. Functional ischemia is an important factor limiting muscular and cardiac performance during the graded exercise stress. The exercise type plays a significant role in developing the velocity of adaptation of cardiovascular system at onset of exercising. Faster adaptation at onset of exercise is more characteristic of sprint and combat sports than representatives of endurance or non-athletes.
\end{abstract}

Keywords: cardiovascular system, adaptation, functional ischemia.

\section{INTRODUCTION}

$\mathrm{E}$

xercise training is associated with adaptations of cardiovascular system (Noakes, 2000; Dickhuth et al., 2004; Duncker, Bache, 2008) and these long-term adaptations are important background in acute response at onset of exercising (Noakes et al., 2001; Calbet et al., 2009). There are many studies designed for the analysis of central and peripheral mechanisms limiting exercise performance. The classical theory (Mitchell, Blomqvist, 1971) explains that exercise is limited after oxygen delivery to the exercising muscles becomes inadequate (Bassett, Howley, 2000; McKay et al., 2009). Cardiac function has to provide an adequate blood supply to all organs, including the skeletal muscles at rest and during exercise, thus the changes in performance and functional state of cardiac muscles during exercising are very important.

Reactivity of the cardiovascular system to acute exercise stress is also an important feature concerning the body abilities during exercising. The fast mobilization of body functions at onset of exercise is very important in many kinds of sport and there are a lot of situations in competitive sport when this ability is a determinant factor or important element of functional capabilities (Платонов, 2004; Ezerskis et al., 2009). The objective of this study was to find out the peculiarities in adjustment of 
cardiovascular system in dependence on the type of adaptation to physical loads during graded stress.

\section{RESEARCH METHODS}

The study participants were 17 voluntary students who were not engaged in the sport training (aged $20.9 \pm 1.21$, body mass index $22.3 \pm 0.38$ ); well-trained athletes (all participant were members of various national teams), i. e. 23 athletes in the endurance group; 19 - sprint group and 21 combat-sport group (box, judo and wrestling).

The subject underwent a bicycle ergometry of incremental increase in provocative workload (graded stress), i. e. a $50 \mathrm{~W}$ increase in workload every 60 seconds (60 revolutions $/ \mathrm{min}$ ) and they exercised to the inability to continue workload or to a predetermined goal (submaximal heart rate) unless distressing cardiovascular symptoms supervened.

Arterial blood pressure (ABP) was measured using Korotkoff method and a computerized ECG analysis system "Kaunas-Workload", developed at the Kaunas University of Medicine, Institute of Cardiology, was employed for 12lead ECG recording and analysis. The changes in RR interval or heart rate (HR), JT interval, STsegment depression and in the ratio of intervals JT/RR were analyzed. A computerized program allowed evaluating the velocity of adaptation of cardiovascular system to exercise, i. e. the index of velocity of adaptation $\left(\mathrm{V}_{\mathrm{Ad}}\right)$, by calculation the difference between the relative changes of JT interval and RR interval as a difference: $\mathrm{V}_{\mathrm{Ad}}=\left(\mathrm{JT}_{\mathrm{i}} /\right.$ $\left.\mathrm{JT}_{0}\right) 100 \%$ - $\left(\mathrm{RR}_{\mathrm{i}} / \mathrm{RR}_{0}\right) 100 \%$.

Statistical analysis. All the data were expressed as mean \pm standard error of the mean (SEM). Hypothesis concerning the difference between means was verified using Student $t$ test for independent and dependent variables. Difference in means was regarded as statistically significant when error probability with respect to criteria was $\mathrm{p}<0.05$.

\section{RESEARCH RESULTS}

The results obtained during the bicycle ergometry of incremental increase in provocative workload showed that the greatest ability to perform the incremental workload was in the endurance group. All participants of the experiment, representatives of endurance group, underwent a $250 \mathrm{~W}$ workload and 60 percent of them - even $350 \mathrm{~W}$. The least working capacity was demonstrated by the participants - representatives of non-athlete group. They were able to reach the workload of 200-250 W. No significant differences $(\mathrm{p}>0.05)$ were found between sprint and combat sport groups. The participants of these cohorts underwent the workload of 250-300 W.

Table presents the values of cardiovascular indices registered during the bicycle ergometry. No statistically significant differences were found in heart rate, arterial blood pressure, JT interval and JT/ $R R$ values between the groups ( $p>0.05)$ at the end of workout of incremental increase the workload.

Table. Values of cardiovascular indices registered before and at the end of the workload during graded stress (bicycle ergometry)

\begin{tabular}{|c|c|c|c|c|c|}
\hline Cohort & $\begin{array}{c}\text { HR, } \\
\mathbf{b} / \mathbf{m i n} .\end{array}$ & $\begin{array}{c}\text { ST-segment } \\
\text { depression, } \\
\mathbf{m V}\end{array}$ & $\begin{array}{c}\text { JT interval, } \\
\mathbf{m s}\end{array}$ & JT/RR & $\begin{array}{c}\text { ABP, } \\
\mathbf{m m H g}\end{array}$ \\
\hline Non-athletes & $\frac{78.3 \pm 2.5}{178.2 \pm 4.7}$ & $\frac{0.07 \pm 0.01}{0.62 \pm 0.05}$ & $\frac{268.2 \pm 3.2}{163.1 \pm 4.6}$ & $\frac{0.358 \pm 0.01}{0.631 \pm 0.03}$ & $\frac{123.2 / 75.6}{198.2 / 31.6}$ \\
\hline Endurance & $\frac{66.4 \pm 2.3}{172.4 \pm 1.8}$ & $\frac{0.05 \pm 0.01}{0.26 \pm 0.07}$ & $\frac{294.3 \pm 3.3}{161.2 \pm 1.2}$ & $\frac{0.343 \pm 0.01}{0.621 \pm 0.02}$ & $\frac{121.6 / 78.1}{193.7 / 35.0}$ \\
\hline Sprint & $\frac{79.4 \pm 2.6}{178.2 \pm 2.9}$ & $\frac{0.08 \pm 0.01}{0.42 \pm 0.06}$ & $\frac{266.5 \pm 3.1}{165.2 \pm 3.4}$ & $\frac{0.353 \pm 0.01}{0.633 \pm 0.02}$ & $\frac{120.5 / 80.2}{189.4 / 36.6}$ \\
\hline Combat sport & $\frac{72.7 \pm 2.5}{178.4 \pm 2.8}$ & $\frac{0.10 \pm 0.01}{0.41 \pm 0.06}$ & $\frac{265.7 \pm 4.0}{162.9 \pm 2.3}$ & $\frac{0.351 \pm 0.01}{0.628 \pm 0.03}$ & $\frac{122.6 / 75.8}{203.1 / 34.5}$ \\
\hline
\end{tabular}

Note. Upper row - before; lower row - maximal values, i. e. at the end of workout; in column of ABP of systolic and diastolic values are presented. 
The results obtained during the study showed that the velocity of adaptation $\left(\mathrm{V}_{\mathrm{Ad}}\right)$ at onset of exercise depended on the residual effects of training. The fastest adaptation at onset of exercise was in sprint group $(16.3 \pm 1.33 \%)$. The values of velocity of adaptation in endurance group were $19.8 \pm 1.34 \%$. The difference between sprint and endurance cohorts was statistically significant $(p<0.05)$. The velocity of adaptation in cohort of non-athletes were the slowest $-21.4 \pm 1.33 \%$. To sum up, the faster adaptation at onset of exercise is quite in character for sprint and combat cohorts than endurance or non-athletes cohorts.

The differences between the cohorts were expressed in values of ST-segment depression at the end of workout, in values of changes of cardiovascular indices at the same grades of the task, in relative changes of cardiovascular indices with the performance, i. e. developed power on bicycle ergometer. Figure presents the values of ST-segment depression registered before the workload and the maximal registered values during exercising. As these figures represent the sum of negative amplitudes of ST-segment depression in 12-leads of ECG, the results obtained by the analysis of this parameter are as follows. No significant functional ischemia was found in endurance cohort during the graded stress $(0.26 \pm$ $0.07 \mathrm{mV}$ ). Only four participants from endurance cohort showed highest ST-segment depression values, but for others there no significant changes were found in this parameter. The highest values of ST-segment depression were registered in nonathlete cohort $(0.62 \pm 0.05 \mathrm{mV})$ and slightly smaller in sprint and combat cohorts $(0.42 \pm 0.06 \mathrm{mV}$ and $0.41 \pm 0.06 \mathrm{mV}$, respectively).

\section{DISCUSSION}

Maximal exercise tests are related to motivation and it is important to take into account the fact that some participants finished the exercising before maximal mobilization of cardiovascular system. In our previous study (Poderys et al., 2005) we showed that the change in the ratio of JR/RR intervals of ECG allowed assessing the dynamics of mobilization of cardiovascular system during the exercise tests or workouts. The studies designed to assess the individual peculiarities of body functioning during the workloads usually have a task to evaluate to what extent the body function was mobilised during the performance of the task. Absolute values such as the heart rate during exercising can be used for these purposes. Such methods are practical but not precise for outlining to what extent the mobilisation of cardiovascular system occurred (Vainoras, 1996, 2002; Poderys, 2000). A special study performed by V. G. Boshkov (Бочков, 1986) showed that activation of physiological systems could be expressed by normalised values in the ratio of underlying indices of the physiological system. These underlying indices of cardiac function can be the ratio of JT and RR intervals (Vainoras, 1996) The JT interval is not independent of the ventricular depolarisation pattern and can be used as an accurate means of following the duration of ventricular depolarisation (Banker et al., 1997) and its changes interrelate with the changes in
Figure. ST-segment depression registered before and during the graded stress
Note. Values of ST-segment depression is a sum of negative amplitudes in 12-leads.

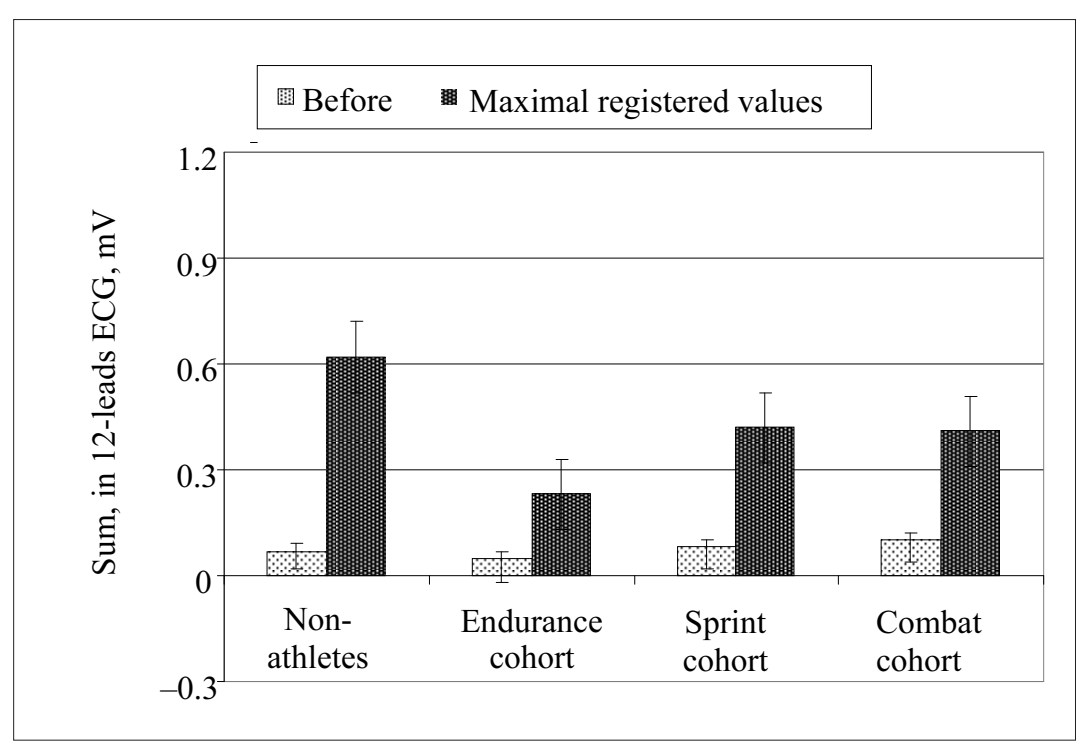


the intensity of metabolism (Vainoras, 1996). The results obtained during this study have shown that the ratio JT/RR can be useful for outlining to what extent a cardiovascular function was mobilised. As it was found in our study, the ratio in JT/RR varied very much alike as it was established by V. G. Boshkow (Бочков, 1986). According to V. G. Boshkow, these biological constants can be expressed mathematically $(1 / \mathrm{e}=0.368$ and $1-1 / \mathrm{e}=$ 0.632). During this study we found that in all groups this ratio was more than 1.62. This value of JT/RR evidenced that the participants of the study performed the workload up to inability to continue it and a full mobilization of functional abilities of the cardiovascular system was achieved .

Individual peculiarities and differences between various cohorts can be assessed making use of the index of velocity of adaptation $\left(\mathrm{V}_{\mathrm{Ad}}\right)$, which represents the difference between the relative changes of RR and JT intervals of ECG. Our previous studies (Poderys et al., 2002; Poderys 2000, 2005) showed that the velocity of adaptation at onset of exercise depended more on the functional state or residual effects of training than on the type of exercise-test. During the study designed to evaluate the changes in the velocity of adaptation in sprint cohort significant changes under the influence of concentrated heavy training loads were found, i. e. $16.3 \pm 1.33 \%$ before training, $26.2 \pm 1.42 \%$ - after 2-week of heavy training, and $20.1 \pm 1.35 \%$ - after one week of recovery (Poderys, 2002). All this allows us to conclude that individual peculiarities and differences between cohorts in the velocity of adaptation of the cardiovascular system at onset of exercise can be evaluated making use of the difference between the relative changes of RR and JT intervals of ECG. The results obtained in this study have shown what a significant role in developing and improving the velocity of adaptation of cardiovascular system at onset of exercise is played by the exercise type or the type of adaptation. The main differences in the content of training between the sprint and endurance cohorts are found in the prevailing interval methods of training in sprint cohort and sustained exercise in endurance events (Платонов, 2004; Ezerskis et al., 2009). Sudden change in the intensity in workloads during the fight is typical of combat events. Thus, these changes could be a possible explanation of differences in the values of the velocity of adaptation between the endurance, sprint or combat cohorts during this study.

Prognostic importance of ischemic episodes detected by ST-segment monitoring with continuous 12-lead ECG during exercise test was emphasized in many investigations (Jernberg, 1999; Yazigi et al., 1998 Vainoras, 2002; Stern, 2002). The fact that myocardial hypoxia causes a progressive cardiac failure was shown by A. V. Hill even at the beginning of XIX century (Hil et al., 1924). When the oxygen supply becomes inadequate it is probable that the heart rapidly diminishes its output avoiding exhaustion in this way. The classical theory (Mitchell, Blomqvist, 1971) proposes that exercise is limited only after oxygen delivery to the exercising skeletal muscles becomes inadequate, inducing anaerobiosis (Bassett, Howley, 1997, 2000). The central governor theory predicts that cardiac output will fall during hypoxia in proportion to the reduction in oxygen delivery to the heart, specifically to prevent hypoxic damage to the heart or other vital organs including, perhaps, the brain and respiratory muscles (Noakes et al., 2001). Our finding that the cohorts showed the highest physical working capacity and the smallest changes of ST-segment depression, and other studies mentioned above the importance of mechanisms related with stress-induced ischemia in the diagnosis of performance abilities.

\section{CONCLUSIONS AND PERSPECTIVES}

1. No significant functional ischemia was found in endurance cohort during the graded stress while it was expressed in non-athlete cohort and slightly in sprint and combat cohorts. Maximal values of other ECG or ABP parameters registered during graded stress did not reveal significant differences between cohorts.

2 . The exercise type plays a significant role on developing and improving the velocity of adaptation of cardiovascular system at onset of exercising. Faster adaptation at onset of exercise is more characteristic of sprint and combat sports than representatives of endurance sport or nonathletes. 


\section{REFERENCES}

Banker, J., Dizon, J., Reiffel, J. (1997). Effects of the ventricular activation sequence on the JT interval. American Journal of Cardiology, 79 (6), 816-819.

Bassett, D. R., Jr and Howley, E. T. (2000). Limiting factors for maximum oxygen uptake and determinants of endurance performance. Medicine and Science in Sports and Exercise, 32, 70-84.

Bassett, D. R., Jr and Howley, E. T. (1997). Maximal oxygen uptake: 'classical' versus 'contemporary' viewpoints. Medicine and Science in Sports and Exercise, 29, 591-603.

Calbet, J. A., Robach, P., Lundby, C. (2009). The exercising heart at altitude. Celluler and Molecular Life Sciences, 66 (22), 3601-3613.

Dickhuth, H. H., Röcker, K., Mayer, F., König, D., Korsten-Reck, U. (2004). (Endurance training and cardial adaptation (athlete's heart)). (Article in German). Herz, 29 (4),373-380.

Duncker, D. J., Bache, R. J. (2008). Regulation of coronary blood flow during exercise. Physiology Reviews, 88 (3), 1009-1086.

Ezerskis, M. (2009). Dynamics of Cardiovascular Functional Indices of Elite Greco-Roman Wrestlers During Annual Trainning Cycle: Summary of the Doctoral Dissertation. Kaunas.

Hill, A. V., Long, C. N. H., Lupton, H. (1924). Muscular exercise, lactic acid and the supply and utilisation of oxygen. Parts I-III. Proceedings of the Royal Society (Lond.), 97, 438-475.

Jernberg, T. B., Lindahl, L., Wallentin (1999). ST-segment monitoring with continuous 12-lead ECG improves early risk stratification in patients with chest pain and ECG nondiagnostic of acute myocardial infarction. Journal of the American College of Cardiology, 34 (5), 1413-1419.

McKay, B. R., Paterson, D. H., Kowalchuk, J. M. (2009). Effect of short-term high-intensity interval training vs. continuous training on $\mathrm{O}_{2}$ uptake kinetics, muscle deoxygenation, and exercise performance. Jounal of Applied Physiology, 107 (1), 128-138.

Mitchell, J. H., Blomqvist, G. (1971). Maximal oxygen uptake. The New England Journal of Medicine, 284, 1018-1022.
Noakes, T. D., Peltonen, J. E., Rusko, H. K. (2001). Evidence that a central governor regulates exercise performance during acute hypoxia and hyperoxia. Journal of Experimental Biology , 204 (Pt 18), 32253234.

Noakes, T. D. (2000). Physiological models to understand exercise fatigue and the adaptations that predict or enhance athletic performance. Scandinavian Journal of Medicine and Science in Sports, 10, 123-145.

Poderys, J., Buliuolis, A., Poderyte, K., Sadzeviciene, R. (2005). Mobilization of cardiovascular function during the constant-load and all-out exercise tests. Medicina (Kaunas), 41 (12), 1048-1053.

Poderys, J. (2000). Acute and Chronic Adaptation of Cardiovascular System to Exercise. Summary of Research Report Presented For Habitation. Kaunas University of Medicine.

Poderys, J. (2002). Acute and chronic adaptation of cardiovasdcular function to sprint or endurance training. Ugdymas. Kūno kultūra. Sportas, 3, 44-48.

Stern, S. (2002). State of the art in stress testing and ischaemia monitoring. Cardiac Electrophysiology Review, 6 (3), 204-208.

Vainoras, A. (2002). Functional model of human organism reaction to load evaluation of sportsmen training effect. Ugdymas. Kūno kultūra. Sportas, 3 (44), 88-93.

Vainoras, A. (1996). Investigation of the Heart Repolarization Process During Rest and Bicycle Ergometry (100-lead and standard 12-lead ECG data): Synopsis of a D. Sc. Habil. Thesis. Kaunas.

Yazigi, A., F. Richa, S., Gebara, F. et al. (1998) Prognostic importance of automated ST-segment monitoring after coronary artery bypass graft surgery. Acta Anaesthesiologica Scandinavica, 42 (5), 532-535.

Бочков, В. Г. (1986). Многовариантность регулирования в биологических системах и новые физиологическые константы: автореферат диссертации на соискание учёной степени кандидата ьиологических наук. Киев.

Платонов, В. Н. (2004). Соревновательная деятельност в спорте. В кн. Система подготовки спортсменов $в$ олимпийском спорте. Киев. С. 109-132 


\title{
ŠIRDIES IR KRAUJAGYSLIŲ SISTEMOS GREITOJI ADAPTACIJA PAKOPOMIS DIDINAMO KRŪVIO METU
}

\author{
Jonas Poderys, Alfonsas Buliuolis, Kristina Poderienè, Vilma Papievienė \\ Lietuvos kūno kultūros akademija, Kaunas, Lietuva
}

\section{SANTRAUKA}

Tyrimo pagrindimas ir hipotezė. Pagrindiné širdies ir kraujagysliu sistemos funkcija yra tiekti organams deguoni ir energines medžiagas, todèl pačios širdies funkcinès būsenos vertinimas yra svarbus.

Tikslas - nustatyti, kaip organizmas adaptuojasi prie pakopomis didinamo fizinio krūvio ir kaip tas krūvis veikia širdies ir kraujagyslių sistemos funkcinų rodiklių kaitos ypatybes.

Metodika. Nesportuojantys asmenys $(\mathrm{n}=17)$ bei greitumo $(\mathrm{n}=23)$, ištvermès $(\mathrm{n}=19)$ ir dvikovos sportininkai $(\mathrm{n}=21)$ atliko pakopomis didinamą fizinị krūvị veloergometru iki negalëjimo tęsti krūvị. Buvo matuojamas arterinis kraujospūdis (AKS) ir registruojama 12-kos standartinių derivacijų elektrokardiograma (EKG). Vertinta ŠSD, RR ir JT intervalų trukmès ir jų santykis (JT/RR), ST-segmento depresija ir adaptacijos greičio rodiklis: $\mathrm{V}_{\mathrm{Ad}}=\left(\mathrm{JT}_{\mathrm{i}} / \mathrm{JT}_{0}\right) 100 \%-\left(\mathrm{RR}_{\mathrm{i}} / \mathrm{RR}_{0}\right) 100 \%$.

Rezultatai. Didejjant atliekamam krūviui, ištvermès sportininkų funkciniai išeminiai reiškiniai nebuvo išreikšti, tačiau tai buvo labai ryšku nesportuojančiuju grupèje ir kiek mažiau - greitumo ir dvikovos sportininku grupèse. Nebuvo aptikta reikšmingo skirtumo tarp grupiu lyginant krūvio metu užregistruotas didžiausias kitų EKG ir AKS rodiklių reikšmes.

Aptarimas ir išvados. Reikšmingas veiksnys, turintis įtakos raumenų ir širdies darbingumui pakopomis didinamo krūvio metu, yra didējantys funkciniai išeminiai reiškiniai miokarde. Širdies ir kraujagyslių sistemos adaptacijos prie krūvio greitis reikšmingai susijęs su adaptacijos pobūdžiu. Didžiausias adaptacijos greitis nustatytas tarp sprinto bėgikų ir dvikovininkų, mažesnis - tarp ištvermès sportininkų ir nesportuojančių asmenų.

Raktažodžiai: širdies ir kraujagyslių sistema, adaptacija, funkcinè išemija. 